FIU Law Review

\title{
The Two Percent: How Florida's Capital Punishment System Defies the Eighth Amendment
}

\author{
Sofia Perla \\ Florida International University College of Law, Sperl013@fiu.edu
}

Follow this and additional works at: https://ecollections.law.fiu.edu/lawreview

Part of the Constitutional Law Commons, Criminal Law Commons, Human Rights Law Commons, Law and Society Commons, Law Enforcement and Corrections Commons, and the Supreme Court of the United States Commons

Online ISSN: 2643-7759

\section{Recommended Citation}

Sofia Perla, The Two Percent: How Florida's Capital Punishment System Defies the Eighth Amendment, 15 FIU L. Rev. 515 (2021).

DOI: https://dx.doi.org/10.25148/lawrev.15.2.12

This Comment is brought to you for free and open access by eCollections. It has been accepted for inclusion in FIU Law Review by an authorized editor of eCollections. For more information, please contact lisdavis@fiu.edu. 


\title{
The Two Percent: How Florida's Capital Punishment System Defies the Eighth AMENDMent
}

\author{
Sofia Perla*
}

\begin{abstract}
In the 1976 case Proffitt v. Florida, the Supreme Court of the United States approved Florida's death penalty statute, which enumerated eight aggravating factors. According to that statute, a finding of at least one of those factors made a first-degree murder conviction eligible for the death penalty. The Court held that these eight factors adequately narrowed, at the legislative level, the class of crimes eligible to receive the death penalty. Since the Supreme Court's decision in Proffitt, the Florida legislature has doubled the number of aggravating factors. The inclusion of these numerous additional aggravating factors avoids the constitutionally required narrowing that must occur, at the legislative level, between those defendants convicted of first-degree murder and those eligible to be sentenced to death. The Supreme Court denied certiorari when a similar challenge was voiced against Arizona's death penalty statute. This denial, and acquiescence in the unfettered addition of aggravating factors, violates the cruel and unusual punishments clause of the Eighth Amendment.
\end{abstract}

I. Introduction

II. The Modern History of Capital Punishment in the United States .. 517

A. Eligibility Versus Selection ................................................. 519

B. Narrowness Beginning in 1976............................................. 520

C. The Problem with Vague Language in Aggravating

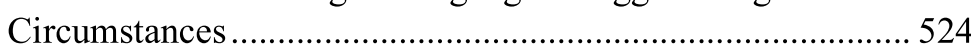

III. The Issue Presented by Hidalgo v. Arizona .................................... 527

A. Hidalgo in the Arizona Supreme Court ................................. 528

B. Hidalgo in the U.S. Supreme Court ........................................529

C. The Impact of Hidalgo in the Arizona Legislature .................. 531

IV. Florida History and Background:..................................................532

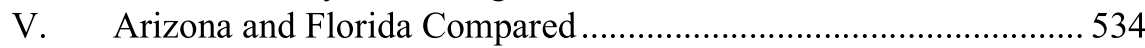

VI. What Is the Solution? .................................................................... 535

* Editor in Chief, FIU Law Review, 2020-2021. J.D. 2021, Florida International University (FIU) College of Law. Thank you to Professor Stephen Harper for his knowledge, guidance, and many lessons; to my parents for their comments and support; and the FIU Law Review staff for their edits and contributions. This comment is dedicated to the fourteen individuals executed by the Federal Government between July 2020 and January 2021 and the 336 individuals on Florida's Death Row (as of Jan. 17, 2021). 


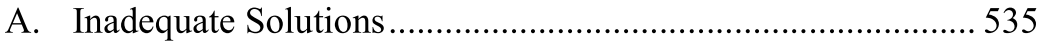

B. Possible Adequate Solutions ..................................................... 537

1. The U.S. Supreme Court Should Revisit the Issue of Adequate Narrowing.

2. A Separate Analysis for States with Narrowing Provisions, Procedures, or Practices in the Eligibility and Selection Phases.

3. Following Oregon's Example ....................................... 538

VII. Conclusion

\section{INTRODUCTION}

In 1972, the United States Supreme Court invalidated the death penalty as unconstitutional nationwide. The arbitrary and capricious imposition of death sentences violated the cruel and unusual punishments clause of the Eighth Amendment. The Constitution demands that states narrow the class of death-eligible murder cases. The Court lifted the restriction in 1976 after states modified their statutes and sought Constitutional approval. Florida's death penalty statute was approved in the same year, with eight aggravating factors, one of which must have been found by a jury before a first-degree murder would be eligible for the death penalty. Today, Florida's death penalty statute boasts sixteen aggravating factors, twice the number approved by the Supreme Court. Since the Court's last reassessment in the late 1970s, the Florida legislature has ignored the narrowing language required by the Court. Part II of this analysis begins by reviewing the modern history of capital punishment in the United States and touches on the concepts of eligibility, selection, narrowness, and vagueness. Part III continues by reviewing the argument made before the U.S. Supreme Court, in Hidalgo v. Arizona, challenging Arizona's death penalty law, suggesting the issue of narrowing is ripe for review. Parts IV and V review Florida's death penalty scheme and offers a comparison to Arizona's death statute. The final parts of this comment review potential solutions and argue that the Court should redefine narrowing, in much more precise terms than have been employed in recent years, before presenting solutions Florida can employ to genuinely and successfully narrow the class of death-eligible murder cases. 


\section{The Modern History of Capital Punishment in the UNITED STATES}

The modern history of capital punishment jurisprudence in the United States began in 1972 with Furman v. Georgia. ${ }^{1}$ The Court released a oneparagraph per curiam opinion invalidating the death penalty throughout the United States. ${ }^{2}$ With each member of the Court writing an individual opinion, five justices of the Supreme Court found the death penalty unconstitutional for violating the "cruel and unusual punishments" clause of the Eighth Amendment; four justices dissented. ${ }^{3}$

The opinions' reasoning varied. Justices Brennan and Marshall opined that capital punishment is per se unconstitutional. Brennan looked to history to guide his opinion, ${ }^{4}$ Marshall looked to evolving standards of decency. ${ }^{5}$ Justices Stewart, White, and Douglas held capital punishment to be unconstitutional as applied. ${ }^{6}$ Stewart began his opinion with the notion that "[t]he penalty of death differs from all other forms of criminal punishment, not in degree but in kind" - a sobering theme in capital punishment jurisprudence. He found a violation of the Eighth Amendment, ${ }^{8}$ not per se, but in its arbitrary and capricious imposition, saying, "death sentences are cruel and unusual in the same way that being struck by lightning is cruel and unusual." Justice White sought to invalidate the death penalty for its infrequent and random use. "[T] infrequency even for the most atrocious of crimes and ... there is no meaningful basis for distinguishing the few cases in which it is imposed from the many cases in which it is not." 10

Even the dissenters shared the same sentiments as the concurring justices. Chief Justice Burger opened his opinion saying, "If we were possessed of legislative power, I would either join with Mr. Justice Brennan and Mr. Justice Marshall or, at the very least, restrict the use of capital punishment to a small category of the most heinous crimes."11 Despite the

Furman v. Georgia, 408 U.S. 238 (1972) (per curiam).

Id. at 239.

Id.

4 Id. at 258-59 (Brennan, J., concurring).

5 Id. at 329 (Marshall, J. concurring).

6 See generally id.

7 Id. at 306 (Brennan, J., concurring).

8 The Eighth Amendment provides, "Excessive bail shall not be required, nor excessive fines imposed, nor cruel and unusual punishments inflicted." U.S. CONST. amend. VIII.

9 Furman, 408 U.S. at 309 (Stewart, J., concurring).

10 Id. at 313 (White, J., concurring).

11 Id. at 375 (Burger, Chief J., dissenting). 
differences in opinion, a central theme ran through the entirety of the decision - to withstand constitutional muster, the imposition of death sentences must not be arbitrary.

The ruling in Furman v. Georgia was the catalyst for thirty-five state legislatures to redraft their capital punishment statutes and remove any threat of arbitrary imposition of death sentences. ${ }^{12}$ Capital punishment was constitutional if it was not arbitrary, so states set out to make that so.

In 1976, Gregg v. Georgia, ${ }^{13}$ alongside several other capital punishment cases, ${ }^{14}$ came before the U.S. Supreme Court and set the gold standard, though not the only standard, for a constitutionally valid death penalty scheme. In its revised statute, Georgia bifurcated the trial and sentencing processes; the judge charged all lesser included offenses supported by the evidence; the jury or judge heard all mitigating and aggravating evidence following the determination of guilt; the jury (or judge in a bench trial) must have found the existence of aggravating factors before a death sentence could be imposed; and, the state supreme court reviewed all death sentences, which, pursuant to the statute, must have been accompanied by a complete record of the trial and separate report by the trial judge or jury. ${ }^{15}$ Aggravating factors, also called aggravating circumstances, are those factual determinations made by a jury that make the particular crime worse than other first-degree murders, for example, a very young or elderly victim. ${ }^{16}$ Aggravating factors can also be thought of as eligibility factors-when one is present, the defendant becomes eligible for the death penalty. ${ }^{17}$ Mitigating evidence is any evidence that may persuade a juror to give life imprisonment over death. ${ }^{18}$ The U.S. Supreme Court requires that the jury review both aggravating and mitigating evidence, or their functional equivalents. ${ }^{19}$

In the same year as Gregg, the United States Supreme Court approved the Florida death penalty statute in Proffitt v. Florida. ${ }^{20}$ Florida's death penalty statute shared many of the same characteristics as the Georgia statute, including a bifurcated trial process and automatic review of every death sentence by the Florida Supreme Court. ${ }^{21}$ In 1976, Florida's revised statute

Gregg v. Georgia, 428 U.S. 153, 180 (1976).

Id.

4 E.g., Woodson v. North Carolina, 428 U.S. 280 (1976); Jurek v. Texas, 428 U.S. 262 (1976).

15 Gregg, 428 U.S. at $162-68$.

16 See generally Gregg, 428 U.S. 153; FLA. STAT. § 921.141(1) (2019).

7 Brown v. Sanders, 546 U.S. 212, 216 n.2 (2006).

8 See generally Lockett v. Ohio, 438 U.S. 586 (1978) (plurality opinion).

19 See generally Hurst v. Florida, 136 S. Ct. 616 (2016); Ring v. Arizona, 536 U.S. 584 (2002); Lockett, 438 U.S. 586.

20 Proffitt v. Florida, 428 U.S. 242 (1976).

21 Id. at 248 (1976); Gregg v. Georgia, 428 U.S. 153, 162-68 (1976). 
enumerated eight aggravating factors. ${ }^{22}$ The Court, in Gregg and Proffitt, found that the revised state statutes sufficiently narrowed the class of defendants eligible for the death penalty through the determination of aggravating factors. This shielded the Georgia and Florida schemes from arbitrary and capricious imposition of death sentences. Narrowing during the eligibility phase of a capital trial, saved Georgia, Florida, and many other states' death penalty statutes following Furman.

\section{A. Eligibility Versus Selection}

In capital punishment jurisprudence, courts discuss the concepts of eligibility and selection. ${ }^{23}$ After the determination of guilt, sentencing begins. Eligibility and selection are two successive determinations, which both take place during sentencing, that must be made before a death sentence may be imposed. ${ }^{24}$ Each determination poses a particular question. Eligibility asks: "Is the defendant in the class of defendants on whom the death penalty could be imposed?" 25 The jury must look to the facts of a particular case or crimerather than the defendant- to determine whether that case is eligible for the death penalty. The selection process asks: "Should this particular defendant receive (or be selected for) a death sentence?"26 The two questions are distinct, occurring in sequence instead of simultaneously.

The Florida death penalty scheme involves several statutes working in conjunction. Pursuant to Section 782.04, Florida Statutes (2019), every firstdegree murder is a capital felony. ${ }^{27}$ Pursuant to Section 775.082 ,

a person who has been convicted of a capital felony shall be punished by death if the proceeding held to determine a sentence according to the procedure set forth in [Section] 921.141 results in a determination that such person shall be punished by death, otherwise such person shall be punished by life imprisonment and shall be ineligible for parole. ${ }^{28}$

Finally, Section 921.141 lays out the process of sentencing a defendant to death. ${ }^{29}$ Section 921.141(1) codifies the bifurcation of the trial and

22 Proffitt, 428 U.S. at 251.

23 Cf. Zant v. Stephens, 462 U.S. 862 (1983).

24 Linda E. CARTer, Ellen S. Kreitzberg \& Scott W. Howe, Understanding Capital PUNISHMENT LAW 141 (4th ed. 2018).
25 Id.
26 Id. (emphasis added)
27 FLA. STAT. \$ 782.04 (2019).
28 FLA. STAT. § 775.082 (2019).
29 Fla. STAT. $\$ 921.141$ (2019). 
sentencing phases. ${ }^{30}$ Following conviction or adjudication of guilt by the jury, the "court shall conduct a separate sentencing proceeding to determine whether the defendant should be sentenced to death or life ...." ${ }^{31}$ Section 921.141(2)(a) codifies the eligibility phase of the sentencing proceeding: "After hearing all of the evidence presented regarding aggravating factors and mitigating circumstances, the jury shall deliberate and determine if the state has proven, beyond a reasonable doubt, the existence of at least one aggravating factor . ..."32 Subsection 921.141(2)(b) further clarifies: "If the jury ... unanimously finds at least one aggravating factor, the defendant is eligible for a sentence of death ...." ${ }^{\prime 3}$ The selection decision comes from the same subsection:

$[T]$ he jury shall make a recommendation to the court as to whether the defendant shall be sentenced to life imprisonment without the possibility of parole or death. The recommendation shall be based on weighing all of the following:

a.) Whether sufficient aggravating factors exist.

b.) Whether aggravating factors exist which outweigh the mitigating circumstances found to exist.

c.) $[\mathrm{W}]$ hether the defendant should be sentenced to life imprisonment without the possibility of parole or to death. ${ }^{34}$

The requirement of narrowing mandated by the U.S. Supreme Court in Gregg involves only the eligibility question.

\section{B. Narrowness Beginning in 1976}

Building upon the brief mention of Gregg in an earlier section, Georgia implemented a number of constitutional protections into its new statutory scheme following Furman. Georgia enumerated aggravating factors, at least one of which the jury was required to find before the defendant was eligible for death. ${ }^{35}$ The jury was given full discretion to review any and all mitigating evidence, giving individualized consideration to the defendant-a concept later required by the U.S. Supreme Court. ${ }^{36}$ Finally, every Georgia death

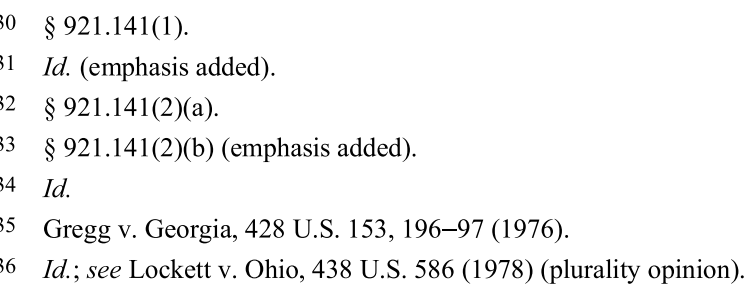


sentence was expedited to the Georgia Supreme Court to conduct a comparative proportional review. ${ }^{37}$

The requirement for the jury to find an aggravating circumstance directly addressed the concern of Justice White's concurrence in Furman by distinguishing those cases involving a crime eligible for death (capital murder) from those without (first-degree murder). ${ }^{38}$ "Georgia did act ... to narrow the class of murderers subject to capital punishment by specifying [ten] statutory aggravating circumstances, one of which must be found by the jury to exist beyond a reasonable doubt before a death sentence can ever be imposed." ${ }^{39}$ Narrowing the class of death-eligible cases through the use of aggravating circumstances, or their functional equivalent, became a requirement for all death penalty statutes per the Court's decisions in Gregg v. Georgia and other similar cases. The guiding principle is this: "To pass constitutional muster, a capital sentencing scheme must genuinely narrow the class of persons eligible for the death penalty and must reasonably justify the imposition of a more severe sentence on the defendant compared to others found guilty of murder." ${ }^{40}$ Therefore, narrowing must take place at the legislative level, through the drafting of a death penalty statute that by its own language makes clear that death is "reserved for only the most aggravated and least mitigated of first-degree murders." 41

Still, the Court has never specified a particular manner in which narrowing must happen. ${ }^{42}$ Those states with statutorily enumerated aggravating circumstances narrow the class of death-eligible cases during the sentencing phase, after finding a defendant guilty of first-degree murder. Those states without statutory "aggravating circumstances" must have another method of distinguishing between death-eligible and non-deatheligible cases. ${ }^{43}$

Texas, for example, cured the arbitrariness problem without the addition of aggravating circumstances by limiting capital homicides to intentional and knowing murders committed in only five situations. ${ }^{44}$ If a murder was not similar to any of the five situations, the defendant was ineligible for death. The Court found that the limited number of situations which rose to the level

37 See generally Gregg, 428 U.S. 153.

38 CARTER, ET AL., supra note 24; Furman v. Georgia, 408 U.S. 238, 311-12 (1972) (White, J., concurring) (per curiam).

39 Gregg, 428 U.S. at 196-97.

40 Lowenfield v. Phelps, 484 U.S. 231, 244 (1988).

41 Urbin v. State, 714 So. 2d 411, 416 (Fla. 1998); see also State v. Dixon, 283 So. 2d 1, 7 (Fla. 1973).

42 CARTER, ET AL., supra note 24, at 144.

43 See generally Gregg v. Georgia, 428 U.S. 153 (1976).

44 Jurek v. Texas, 428 U.S. 262, 268 (1976). 
of capital murder "serves much the same purpose" as enumerated aggravating factors. ${ }^{45}$ "By narrowing its definition of capital murder, Texas has essentially said that there must be at least one statutory aggravating circumstance in a first-degree murder case before a death sentence may even be considered." ${ }^{\prime 46}$ Ultimately, the Court approved Texas's scheme and found that it satisfied the narrowing requirement, creating a potentially smaller class of death-eligible murders than statutes using aggravating circumstances. ${ }^{47}$

Following the Court's holding in Furman, North Carolina and Louisiana sought to eliminate all caprice and arbitrariness by mandating death sentences for all first-degree murder convictions. ${ }^{48}$ When North Carolina's statute was challenged in the U.S. Supreme Court, the majority opined that North Carolina's revised statute resolved the issue of arbitrary administration but created another problem by not comporting with evolving standards of decency and human dignity. ${ }^{49}$ "Consideration of both the offender and the offense in order to arrive at a just and appropriate sentence has been viewed as a progressive and humanizing development." ${ }^{.50}$ By requiring a death sentence for every first-degree murder conviction, North Carolina's revised statute permitted no individualized determination of the particular case and therefore no narrowing of the class of cases eligible for the death penalty.

We believe that in capital cases the fundamental respect for humanity underlying the Eighth Amendment requires consideration of the character and record of the individual offender and the circumstances of the particular offense as a constitutionally indispensable part of the process of inflicting the penalty of death. This conclusion rests squarely on the predicate that the penalty of death is qualitatively different from a sentence of imprisonment, however long. ${ }^{51}$

In Roberts $v$. Louisiana, the Court similarly invalidated Louisiana's death penalty statute mandating the imposition of a death sentence whenever the jury found the defendant guilty of first-degree murder. ${ }^{52}$ The statute left any "qualification or recommendation which a jury might add to its verdictsuch as a recommendation of mercy where the verdict is guilty of first-degree

45 Id. at 270

46 Id. at 276.

47 Id.

48 N.C. GEN. STAT. § 14-17 (1975). See generally Woodson v. North Carolina, 428 U.S. 280 (1976); Roberts v. Louisiana, 428 U.S. 325 (1976).

49 Woodson, 428 U.S. at 303.

$50 \quad I d$. at 304.

51 Id. at 304-05.

52 See Roberts, 428 U.S. at 331. 
murder-... without any effect." ${ }^{13}$ In Louisiana and in North Carolina, if jurors wished not to sentence a convicted first-degree murderer to death, they were forced the violate the court's order. ${ }^{54}$ The Roberts Court found "an element of capriciousness in making the jurors' power to avoid the death penalty dependent on their willingness to accept this invitation to disregard the trial judge's instructions." 55 The imposition of death sentences in these cases became arbitrary, and therefore unconstitutional, in another sensethey were imposed without individualized consideration for the defendant. The Court's opinions in Woodson v. North Carolina and Roberts v. Louisiana highlight the importance of narrowing at the eligibility phase. ${ }^{56}$

As the Court further defined the narrowing requirement, the function began to take the form of a triangle. In a since-overturned case, Justice Brennan dissented from the majority to educate Justice Scalia on the narrowing requirement, borrowing from a visual description used by the Georgia Supreme Court:

All cases of homicide of every category are contained [at the base of] the pyramid.... The first plane of division above the base separates from all homicide cases those which fall into the category of murder.... The second plane separates from all murder cases those in which the penalty of death is a possible punishment. This plane is established by statutory definitions of aggravating circumstances ... [A] given case may not move above this second plane unless at least one statutory aggravating circumstance exists.... The third plane separates, from all cases in which a penalty of death may be imposed, those cases in which it shall be imposed. There is an absolute discretion in the factfinder to place any given case below the plane and not impose death.... [T] he factfinder considers all evidence in extenuation, mitigation and aggravation of punishment. . . 57

A figure illustrates Justice Brennan's passage.

\footnotetext{
53 Id

54 See Woodson, 428 U.S. at 304; Roberts, 428 U.S. at 331.

55 Roberts, 428 U.S. at 335.

56 Woodson, 428 U.S. 280.

57 Walton v. Arizona, 497 U.S. 639, 716-18 (1990).
} 
[Vol. 15:515

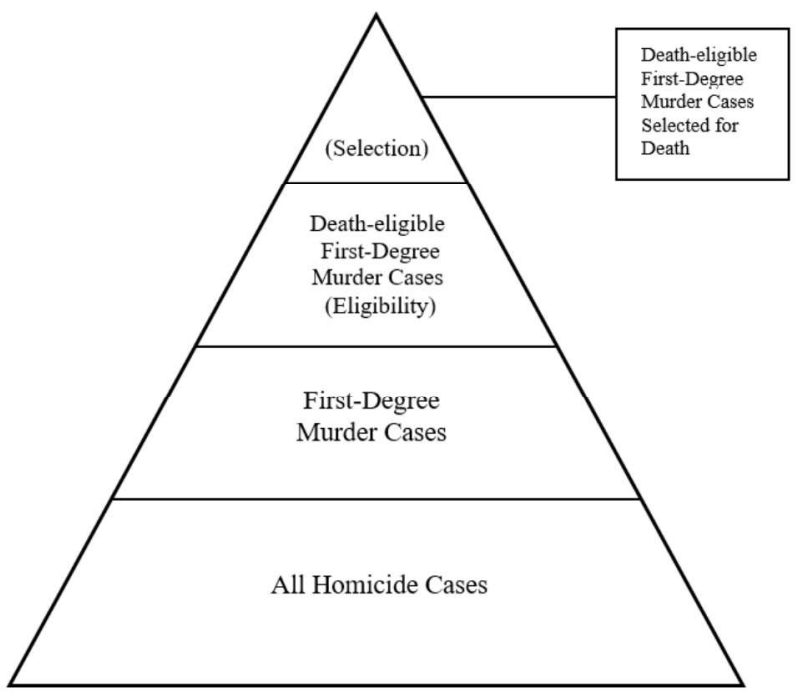

Our discussion takes place only in the Eligibility plane of the triangle. Brennan and the Georgia Supreme Court's employment of a triangle illustrates the necessary narrowing that must occur between the plane containing first-degree murders and the plane with first-degree murders eligible for the death penalty.

\section{The Problem with Vague Language in Aggravating Circumstances}

After demanding compliance with the narrowing requirement, the focus shifted to the vagueness of the language used within the aggravating circumstances. Gregg outlined three criteria to satisfy the narrowing requirement. $^{58}$ The first criterion involves the issue discussed abovenarrowing the class of cases eligible for the death penalty. ${ }^{59}$ The second criterion requires the jury to have guided discretion when reviewing aggravating and mitigating evidence to produce a non-discriminatory, nonarbitrary sentence. ${ }^{60}$ The final criterion requires the aggravating factors to be defined in a manner that is not vague. ${ }^{61}$ In other words, the language of the aggravating factors must be precise enough to instruct the jury on exactly

\footnotetext{
58 CARTER, ET AL., supra note 24, at 152.

59 Id.

60 Id. (citing Gregg v. Georgia, 428 U.S. 153, 198 (1976)).

61 Id. (citing Gregg v. Georgia, 428 U.S. 153, 195 n.46 (1976)).
} 
what they must find before imposing a death sentence. In Zant v. Stephens, the Court recognized the danger of vague language in relation to the narrowing requirement. Zant commands that "an [individual] aggravating circumstance must genuinely narrow the class of persons eligible for the death penalty and must reasonably justify the imposition of a more severe sentence on the defendant compared to others found guilty of murder." 62 Therefore, the function of all the aggravating factors together and the function of individual factors is the same- to narrow the class of deatheligible murders.

Still, some amount of vagueness is necessary to account for those situations that do not fall within the precise, objective aggravating circumstances, yet where the jury may feel compelled to impose a sentence of death. Common aggravators that account for these situations include "extremely heinous, atrocious, and cruel" and "cold, calculated, and premeditated." ${ }^{63}$ However, too much vagueness poses several problems.

Primarily, vague language fails to inform the jury of what it must find before imposing a sentence of death. ${ }^{64}$ Another problem that arises is the wider reach of the aggravating circumstances when viewed collectively ${ }^{65}$ In its review of aggravating circumstances with potentially vague language, the Court has tended to focus on whether an aggravating circumstance is clear enough to inform the jury and narrow the class of cases eligible for the death penalty ${ }^{66}$ If the Court finds that a vague aggravating circumstance achieves even some narrowing, then the Court will approve the aggravating circumstance, despite its vagueness ${ }^{67}$ Additionally, if vague language in an aggravating circumstance is coupled with a limiting instruction, the imprecision of the language becomes acceptable because the jury is guided by the instruction. ${ }^{68}$

In Godfrey v. Georgia, the Supreme Court invalidated an aggravating factor in Georgia's death penalty statute, which used the language "outrageously or wantonly vile, horrible or inhuman," as too vague. ${ }^{69}$ The majority reasoned that with this language, theoretically every first-degree murder could fall in this category. ${ }^{70}$ The aggravating circumstance failed both

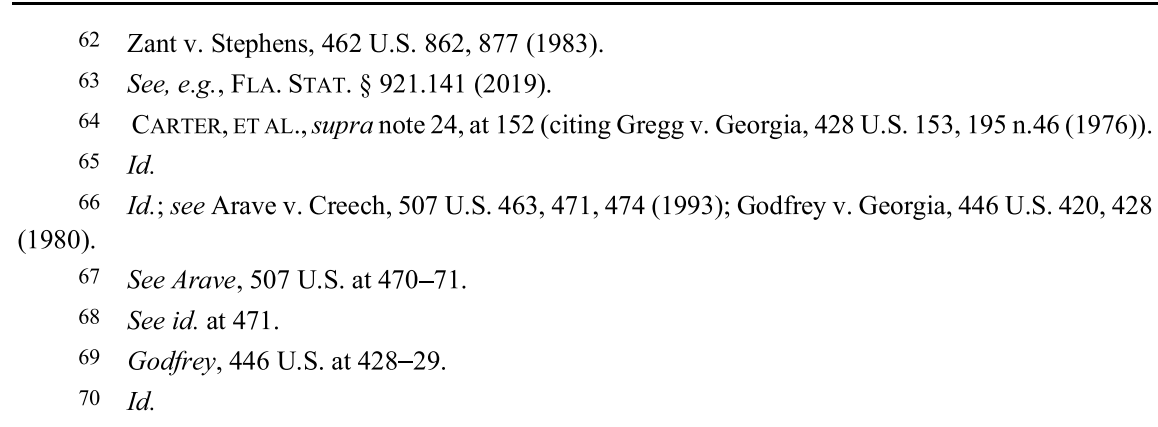


to narrow the class of death-eligible cases and to instruct the jury on what it must find before imposing a sentence of death under the particular aggravating circumstance. ${ }^{71}$

Contrast the holding in Godfrey and the language of the relevant aggravating factor with that of the challenged circumstance in Arave $v$. Creech. Presenting a similar issue, Arave challenged the validity of an aggravating circumstance in Idaho's death penalty statute which used the language "by the murder, or circumstances surrounding its commission, the defendant exhibited utter disregard for human life."72 In a prior case, this aggravating circumstance was qualified by the Idaho Supreme Court by a limiting instruction that read, "The phrase is meant to be reflective of acts or circumstances surrounding the crime which exhibit the highest, the utmost, callous disregard for human life, i.e., the cold-blooded, pitiless slayer." ${ }^{73}$ In Arave, the U.S. Supreme Court approved the language of the aggravating circumstance coupled with the limiting instruction. ${ }^{74}$ The Court held that the limiting instruction placed on the aggravating circumstance by the Idaho Supreme Court indicated that the phrase "utter disregard" referred to actions taken by a "cold-blooded, pitiless slayer." 75 Using the commonplace or dictionary definition of these words, the Court next determined that although the word "pitiless" alone may not achieve narrowing, the additional requirement that the defendant be "cold-blooded" successfully achieved narrowing. ${ }^{76}$

By requiring that individual aggravating circumstances use only somewhat narrow language, the Court contradicts the heavy emphasis placed on the narrowing requirement in the cases immediately following Furman. This analysis ignores the overall effect of the aggravating factors, even when an individual aggravating factor seemingly achieves narrowing. ${ }^{77}$ If every aggravator is only somewhat narrow, the aggravators together cannot genuinely narrow the class of cases eligible for the death penalty. In these opinions, the Court followed its trend of approving narrowing that occurs at least somewhat, despite the manner in which the narrowing was achieved. ${ }^{78}$

71 See id. at 433.

Arave, 507 U.S. at 465.

See State v. Osborn, 631 P.2d 187, 201 (Idaho 2019).

Arave v. Creech, 507 U.S. 463, 471-72 (1993).

Id.

Id.

CARTER, ET AL., supra note 24, at 152.

8 See generally Arave, 507 U.S. 463. 


\section{The IsSUe Presented by HIDALGO V. ARIZONA ${ }^{79}$}

Since the U.S. Supreme Court reviewed states' revised statutes in the late 1970s, the Court has largely abandoned the narrowing analysis. The Court has not granted certiorari on the issue of inadequate narrowing in decades and has seemingly forgotten the strong language it used to initially require genuine narrowing and explain its importance.

Following Gregg, Woodson, and other similar cases, states were required to ensure their death penalty statutes genuinely narrowed the class of cases eligible for the death penalty at the legislative level.$^{80}$ Like most states, Arizona complied with this requirement through the employment of aggravating circumstances. ${ }^{81}$ Also like most other states, the number of aggravating factors has grown since the death penalty was reapproved in $1976{ }^{82}$ Following Furman, Arizona drafted its death penalty statute to include seven aggravating factors ${ }^{83}$ By 2018 , Arizona's death penalty statute had doubled the number of aggravating factors to fourteen. ${ }^{84}$

Under this fourteen-aggravators framework, Arizona defendant, Hidalgo, was accused of agreeing to kill and killing an individual in exchange for one thousand dollars from a gang member and the incidental killing of another individual present at the scene. ${ }^{85}$ The jury found Hidalgo guilty of first-degree murder and determined the presence of four aggravating factors with respect to the first victim and three aggravating factors with respect to the second victim..$^{86}$ The jury sentenced Hidalgo to death. ${ }^{87}$

Hidalgo appealed to the Arizona Supreme Court and eventually the Supreme Court of the United States, twice presenting the same argument. ${ }^{88}$ Hidalgo alleged that because the number of statutory aggravating

79 Hidalgo v. Arizona, 138 S. Ct. 1054, 1056 (2018).

80 See, e.g., Zant v. Stephens, 462 U.S. 862 (1976).

81 ARIZ. REV. STAT. § 13-454 (LexisNexis 1973).

82 Compare Fla. STAT. $§ 921.141$ (LexisNexis 2019), with FlA. STAT. AnN. $\$ 921.141$ (LexisNexis 1976-77)

83 ARIZ. REV. STAT. § 13-454 (LexisNexis 1973).

84 ARIZ. REV. STAT. § 13-751(F) (LexisNexis 2018). After an amendment to the Arizona statute in 2019 eliminating four aggravating factors, the current Arizona statute contains ten aggravating factors. This discussion will primarily refer to the 2018 version of the statute, which was the basis for the arguments made in State v. Hidalgo, 390 P.3d 783, 787 (Ariz. 2017), and Hidalgo v. Arizona, 138 S. Ct. 1054 (2018).

85 State v. Hidalgo, 390 P.3d at 787. To avoid confusion with the U.S. Supreme Court Hidalgo case, I will continue to reference the state supreme court case by its full name, including where the citation is a "short cite."

86 Id.

87 Id.

88 Compare State v. Hidalgo, 390 P.3d 783 (Ariz. 2017), with Hidalgo v. Arizona, 138 S. Ct. 1054 (2018). 
circumstances had doubled since Gregg, the Arizona death penalty statute failed to genuinely narrow the class of cases eligible for the death penalty, as required by Zant $v$. Stephens. ${ }^{89}$ To support this claim, Hidalgo's defense team submitted public records requests for 866 first-degree murder cases from Maricopa County, Arizona, the county where Hidalgo was charged. ${ }^{90}$ The evidence from the cases suggested that in 856 of the 866 cases, an aggravating circumstance was determined to be present by the jury. ${ }^{91}$ This amounted to approximately ninety-eight percent of all first-degree murder cases in Maricopa County being death eligible. ${ }^{92}$

With just two percent of all first-degree murder cases shielded from a death sentence, Hidalgo argued, "Arizona's scheme utterly fails to [narrow]," and "the long experiment launched by Gregg ... has failed." 93

\section{A. Hidalgo in the Arizona Supreme Court}

In the State Supreme Court, Hidalgo lost. ${ }^{94}$ The Arizona court operated under the assumption that "Hidalgo is right in his factual assertion that nearly every charged first degree murder could support at least one aggravating circumstance." 95 The court assumed the study's findings to be true, yet thought Hidalgo was "mistaken ... insofar as he focuses only on the legislatively defined aggravating circumstances." 96 The court said that use of those circumstances "is not the only way in which Arizona's sentencing scheme narrows the class of persons eligible for death." ${ }^{.97}$

Arizona's highest court held that the statistics presented by Hidalgo showed acceptable narrowing for two reasons: (1) aside from the aggravating circumstances, narrowing can be accomplished by prosecutors and juries, and (2) each individual aggravator accomplishes some narrowing, even if in the aggregate very few cases are eliminated from those eligible for death. ${ }^{98}$ The court further held that the state's death penalty scheme successfully narrowed

89 Compare State v. Hidalgo, 390 P.3d 783 (Ariz. 2017), with Hidalgo v. Arizona, 138 S. Ct. 1054 (2018), and Zant v. Stephens, 462 U.S. 862, 877 (1976).

90 Hidalgo, 138 S. Ct. at 1056.

91 State v. Hidalgo, 390 P.3d at 789.

92 Hidalgo, 138 S. Ct. at 1056.

93 See Petition for Writ of Certiorari at 3, Hidalgo v. Arizona, 138 S. Ct. 1054 (2017) (No. 17 251).

94 State v. Hidalgo, 390 P.3d at 798.

95 Id. at 791.

96 Id.

97 Id. at 791-92.

98 See Petition for Writ of Certiorari at 3, Hidalgo v. Arizona, 138 S. Ct. 1054 (2017) (No. 17-251) (emphasis in original). 
the class of individuals eligible for the death penalty in five other ways: (1) Arizona's first-degree murder statute, (2) the identified aggravating circumstances, (3) the fact that the State must prove one or more of the alleged aggravating circumstances beyond a reasonable doubt, (4) mandatory appellate review, and (5) individualized sentencing determinations through the consideration of mitigating circumstances. ${ }^{99}$

Arizona's focus on the effect of only individual aggravating circumstances, as opposed to their aggregate effect, tracks the Supreme Court's typical analysis when determining whether an aggravating circumstance adequately narrows. ${ }^{100}$ When petitioning the U.S. Supreme Court for certiorari, Hidalgo alleged that this holding ignores Supreme Court precedent that "[t]he 'legislature' must provide a means of 'narrow [ing] the class of death-eligible murderers,' and the Arizona legislature certainly has not." 101 Without saying as much, Hidalgo implied that the U.S. Supreme Court has, too, failed to adhere to its requirement that the legislature must genuinely narrow the class of cases eligible for the death penalty.

\section{B. Hidalgo in the U.S. Supreme Court}

The United States Supreme Court denied certiorari for Hidalgo. ${ }^{102}$ Uncomfortable ignoring the issue entirely, however, Justice Breyer authored a concurring opinion, joined by Justices Ginsburg, Sotomayor, and Kagan. ${ }^{103}$ Breyer begins by remarking that Hidalgo's petition asks "an important Eighth Amendment question." ${ }^{104} \mathrm{He}$ continues with an overview of the eligibility and selection phases and a history of the narrowing requirement, much like the organization of this analysis. ${ }^{105}$ Breyer emphasizes, as did Hidalgo's petition for certiorari, that '[t]o satisfy the 'narrowing requirement,' a state legislature must adopt 'statutory factors which determine death eligibility' and thereby 'limit the class of murderers to which the death penalty may be applied." ${ }^{106}$ Breyer then discusses narrowing and the various ways in which it can be achieved, noting that Arizona, the state at issue, has chosen to

99 Hidalgo v. Arizona, 138 S. Ct. 1054, 1056-57 (2018).

100 See CARTER, ET AL., supra note 24, at 152; see also infra Section II.C.

101 See Petition for Writ of Certiorari at 3, Hidalgo v. Arizona, 138 S. Ct. 1054 (2017) (No. 17251) (quoting Lowenfield v. Phelps, 484 U.S. 233, 246 (1988)).

102 Hidalgo, $138 \mathrm{~S}$. Ct. at 1054.

103 Id.

104 Id.

105 See id. at 1054-56.

106 Id. at 1054 (quoting Brown v. Sanders, 546 U.S. 212, 216 n.2 (2006)) (emphasis in original). 
comply with this requirement through the addition of aggravating circumstances, chosen by the state legislature. ${ }^{107}$

Justice Breyer criticizes the Arizona Supreme Court for its faulty analysis. The state court called the petitioner "mistaken" for assuming that the legislatively defined aggravating circumstances are the only means by which Arizona's sentencing scheme can narrow the class of persons eligible for death. ${ }^{108}$ However, the Arizona court itself was mistaken; Justice Breyer emphasizes this point. Referring to the five other ways in which the Arizona Supreme Court claimed that its death penalty scheme adequately narrowed, ${ }^{109}$ Breyer notes that, contrary to the State Supreme Court's assertion, the Arizona first-degree murder statute does not achieve any narrowing because Arizona uses aggravating circumstances instead of designating some murders as capital and all others as first-degree. ${ }^{110}$

Arizona's second assertion, that the statutorily defined aggravating circumstances achieve sufficient narrowing, is non-sensical because Arizona issued its opinion under the assumption that Hidalgo's figures were correct and the aggravating circumstances do not, in fact, narrow. ${ }^{111}$ Breyer discredits Arizona's third and fourth reasons for claiming successful narrowing (beyond a reasonable doubt standard and mandatory appellate review) calling them "beside the point-they do not show the necessary legislative narrowing that our precedents require." 112 Breyer distinguishes Arizona's final claim as nonapplicable. Individualized sentencing determinations concern the selection phase. ${ }^{113}$ Hidalgo asks this question during the eligibility phase. Ultimately, Breyer asserts that Arizona misapplied U.S. Supreme Court precedent by ignoring the requirement that narrowing occur "at the stage of legislative definition." 114 Every rationale the Arizona Supreme Court provided moved away from the legislative function, emphasizing prosecutors, juries, appellate review, and other mistaken claims. ${ }^{115}$

107 Id. at $1055-56$.

108 State v. Hidalgo, 390 P.3d 783, 791 (Ariz. 2017).

109 They were: "(1) Arizona's first-degree murder statute; (2) the identified aggravating circumstances; (3) the fact that the State must prove one or more of the alleged aggravating circumstances beyond a reasonable doubt; (4) the existence of mandatory appellate review; and (5) Arizona's statutory provisions applicable to individualized sentencing determinations through consideration of mitigating circumstances." Hidalgo, $138 \mathrm{~S}$. Ct. at 1057. See also supra text accompanying note 99.

110 Hidalgo, 138 S. Ct. at 1057.

111 Id.; State v. Hidalgo, 390 P.3d at 791.

112 Hidalgo, $138 \mathrm{~S} . \mathrm{Ct}$. at 1057.

113 Id.

114 Id. (quoting Zant v. Stephens, 462 U.S. 862, 878 (1976)) (emphasis in original).

115 See Hidalgo, 138 S. Ct. at 1057. 
Despite Breyer's persuasive concurrence, the United States Supreme Court denied certiorari. ${ }^{116}$ At the trial level, Hidalgo requested an evidentiary hearing to establish that the statistics presented by Hidalgo- that the aggravating circumstances listed in Arizona's death penalty statute apply to virtually every first-degree murder case in Arizona-were true through witness testimony, expert testimony, and documentary evidence. ${ }^{17}$ This request was denied. ${ }^{118}$ Without witness testimony, expert testimony, and documentary evidence tending to prove the proffered statistics, the evidentiary record received by the United States Supreme Court was limited and "largely unexamined by experts and the courts below." 119 The Court lacks evidence indicating which aggravating factors tend to be the most inclusive and why, and information indicating whether an empirical study would bolster the claims made by Hidalgo. Breyer notes, "Capital defendants may have the opportunity to fully develop a record with the kind of empirical evidence that [Hidalgo] points to here. And the issue presented in this petition will be better suited for certiorari with such a record." ${ }^{120}$ If the record had been fuller, with empirical evidence to support Hidalgo's own findings, the Court very well may have granted certiorari. In other words, the issue is ripe for review.

\section{The Impact of Hidalgo in the Arizona Legislature}

Although approved by the Arizona Supreme Court and denied certiorari by the United States Supreme Court, the Arizona legislature set out to revise its death penalty scheme. ${ }^{121}$ Following the Hidalgo case, Arizona Governor Doug Ducey signed into law legislation that will eliminate three of the fourteen aggravating factors contained within Arizona's death penalty statute. ${ }^{122}$ The three factors to be removed are: "(1) the defendant knowingly created a grave risk of death to another person in addition to the person murdered, (2) the offense was committed in a cold, calculated manner

\footnotetext{
116 Id.

117 Id.

118 Id.

119 Id.

120 Id.

121 Lauren Castle, It Just Got a Bit Tougher to Get the Death Penalty in Arizona, REPUBLIC (Apr. 10, 2019), https://www.azcentral.com/story/news/politics/legislature/2019/04/10/governor-doug-duceysigns-bill-arizona-death-penalty-law-sen-eddie-farnsworth/3365922002/.

122 Id.
} 
without a pretense of moral or legal justification, and (3) the defendant used a 'remote stun gun' during the crime."123

Although the legal defense community calls the bill a step in the right direction, Rebecca Baker, a legislative liaison for the Maricopa County Attorney's Office, informed the Senate Judiciary Committee that the enumerated circumstances that will be eliminated by the new law "have proven to historically not be the most persuasive factors when prosecuting death penalty cases." 124 Therefore, although the bill is an attempt to limit how many people will qualify for the death penalty, the elimination of infrequently relied upon factors will limit the alteration's efficacy. The new bill, however, does have the effect of nulling the statistics presented by Hidalgo. ${ }^{125}$ Some of the aggravating factors on which the statistics are based are no longer included in the count. Another capital defendant cannot now make the same argument as Hidalgo, relying on his statistics. Another study must be conducted, and another evidentiary hearing requested.

\section{FLORIDA HISTORY AND BACKGROUND}

As mentioned, following Furman, thirty-five states, including Florida, revised their death penalty statutes to remove any caprice and arbitrariness. In Proffitt v. Florida, the Supreme Court approved Florida's death penalty statute. ${ }^{126}$ To comply with Furman, the Florida legislature bifurcated the trial and sentencing processes; required the judge to weigh any evidence tending to show aggravating circumstances and mitigating evidence; ${ }^{127}$ required a trial court which imposes a death sentence to "set forth in writing" its findings upon which the sentence of death is based, including which aggravating

123 Id. The 2019 Amendment to the Arizona death statute also eliminated a fourth factor, which read, "The defendant committed the offense as consideration for the receipt, or in expectation of the receipt, of anything of pecuniary value." Compare ARIZ. REV. STAT. § 13-751(F) (LexisNexis 2018), with ARIZ. REV. STAT. § 13-751(F) (LexisNexis 2020).

124 Id.

125 See Petition for Writ of Certiorari at 9-10, Hidalgo v. Arizona, 138 S. Ct. 1054 (2017) (No. 17-251).

126 Proffitt v. Florida, 428 U.S. 242, 259-60 (1976).

127 In Ring v. Arizona, the United States Supreme Court reviewed Arizona's death penalty statute on the issue that the jury submitted only an advisory opinion to the judge, who made the final determination of the existence of any aggravating factors, and subsequently decided the decision of life or death. The Court invalidated Arizona's statute holding that the Sixth Amendment required that a jury find all facts within the case. Whether an aggravating circumstance is present constitutes a factual determination, so the Sixth Amendment requires that the jury-not the judge-determine the existence of any aggravating circumstances. Ring v. Arizona, 536 U.S. 584, 609 (2002). Florida's death penalty statute mirrored Arizona's death penalty statute at the time of the Ring decision. However, it was not until Hurst v. Florida in 2016 that the United States Supreme Court invalidated this aspect of the Florida death penalty scheme. Nevertheless, the result is the same: now, a jury must unanimously decide any aggravating circumstances. Hurst v. Florida, 136 S. Ct. 616, 624 (2016). 
circumstances were relied upon; and provided for automatic review by the Supreme Court of Florida for all death sentences. ${ }^{128}$ At the time Furman was decided, the approved Florida statute contained eight aggravating factors. ${ }^{129}$ Today, Florida's statute boasts sixteen aggravating factors:

a) The capital felony was committed by a person previously convicted of a felony and under sentence of imprisonment or placed on community control or on felony probation.

b) The defendant was previously convicted of another capital felony or of a felony involving the use or threat of violence to the person.

c) The defendant knowingly created a great risk of death to many persons.

d) The capital felony was committed while the defendant was engaged, or was an accomplice, in the commission of, or an attempt to commit, or flight after committing or attempting to commit, any: robbery; sexual battery; aggravated child abuse; abuse of an elderly person or disabled adult resulting in great bodily harm, permanent disability, or permanent disfigurement; arson; burglary; kidnapping; aircraft piracy; or unlawful throwing, placing, or discharging of a destructive device or bomb.

e) The capital felony was committed for the purpose of avoiding or preventing a lawful arrest or effecting an escape from custody.

f) The capital felony was committed for pecuniary gain.

g) The capital felony was committed to disrupt or hinder the lawful exercise of any governmental function or the enforcement of laws.

h) The capital felony was especially heinous, atrocious, or cruel.

i) The capital felony was a homicide and was committed in a cold, calculated, and premeditated manner without any pretense of moral or legal justification.

j) The victim of the capital felony was a law enforcement officer engaged in the performance of his or her official duties.

k) The victim of the capital felony was an elected or appointed public official engaged in the performance of his or her official

128 Proffitt, 428 U.S. at 250. On October 29, 2020, the Florida Supreme Court retreated from its fifty-year commitment to automatic review of all death sentences by the court with its decision in Lawrence v. State, 308 So. 3d 544 (Fla. 2020).

129 Proffitt, 428 U.S. at 251. 
duties if the motive for the capital felony was related, in whole or in part, to the victim's official capacity.

1) The victim of the capital felony was a person less than 12 years of age.

m) The victim of the capital felony was particularly vulnerable due to advanced age or disability, or because the defendant stood in a position of familial or custodial authority over the victim.

n) The capital felony was committed by a criminal gang member. ..

o) The capital felony was committed by a person designated as a sexual predator ... or a person previously designated as a sexual predator who had the sexual predator designation removed.

p) The capital felony was committed by a person subject to an injunction ... or a foreign protection order accorded full faith and credit ..., and was committed against the petitioner who obtained the injunction or protection order or any spouse, child, sibling, or parent of the petitioner. ${ }^{130}$

Of these sixteen aggravating circumstances, just two of these are coupled with limiting instructions, per the Florida Supreme Court, to clarify the vague terms used, and only one must be accompanied by statutory definitions (aggravating circumstances $h, i$, and $n$, respectively). ${ }^{131}$ To further emphasize their breadth, many of the aggravating circumstances contain the disjunctive connecter "or," essentially combining several factual circumstances into a single "aggravating factor." If every factual or qualifying circumstance was enumerated individually, nearly fifty individual facts or determinations, if found by the jury, would fall within the sixteen enumerated aggravating factors. ${ }^{132}$ The only narrowing achieved by the Florida death penalty statute is of the extremely small class of first-degree murderers ineligible for a death sentence.

\section{ARIZONA AND FLORIDA COMPARED}

In Hidalgo v. Arizona, the defendant-petitioner noted the fourteen aggravating circumstances contained in the Arizona death penalty statute. ${ }^{133}$ With these fourteen aggravating factors, in one Arizona county, nearly ninety-eight percent of all first-degree murder cases qualified as a capital

130 FLA. STAT. ANN. § 921.141 (LexisNexis 2019).

131 Fla. Std. Jury Instr. (Crim.) 7.11(a); see also Arave v. Creech, 507 U.S. 463, 477 (1993).

132 FLA. STAT. ANN. § 921.141 (LexisNexis 2019).

133 Hidalgo v. Arizona, 138 S. Ct. 1054, 1057 (2018). 
murder case- 856 of 866 cases. ${ }^{134}$ Florida has sixteen aggravating circumstances comprising nearly fifty distinct facts or determinations. Eight of Arizona's aggravating circumstances mirror some or all of the language used in the Florida death penalty statute. ${ }^{135}$ This suggests that where fourteen aggravating circumstances qualified ninety-eight percent of Arizona's firstdegree murders as capital murders, Florida's sixteen aggravating circumstances will produce an even higher percentage of capital murder cases and an even smaller percentage of murder cases ineligible for the death penalty. Although this issue was never addressed by the United States Supreme Court, Justices Breyer, Sotomayor, and Kagan should maintain their trepidations and concerns. ${ }^{136}$ It appears they are growing.

\section{WHAT IS THE SOLUTION?}

In his Petition for Certiorari, Hidalgo argues that a class of two percent of first-degree murderers insulated from the death penalty is an unconstitutional failure to adequately narrow. ${ }^{137}$ Yet, he did not proffer a percentage or other solution that amounts to constitutionally sufficient narrowing.

\section{A. Inadequate Solutions}

The fundamental principle underlying the Supreme Court's narrowing requirement is this: in order to pass muster, a capital sentencing scheme must genuinely narrow the class of persons eligible for the death penalty at the legislative level. ${ }^{138}$

Inadvertently, the Arizona Supreme Court described several inadequate remedies for achieving narrowing which read like adequate solutions. First, the State Supreme Court points to the statute's "beyond a reasonable doubt language," arguing that placing the highest burden on the State necessarily narrows the class of death-eligible cases. ${ }^{139}$ This solution fails for two reasons. First, as Justice Breyer notes in his concurrence, this argument

135 Compare ARIz. Rev. Stat. § 13-751(F)(2)-(7), (9), (10) (2018), with Fla. Stat. AnN. § 921.141(6)(b), (c), (f), (h), (e), (l), (m), (j) (LexisNexis 2019) (respectively).

136 Justice Ruth Bader Ginsburg passed away on September 18, 2020. Biography of Associate $\begin{array}{lllll}\text { Justice Ruth Bader } & \text { Ginsburg, } & \text { SuP. }\end{array}$ https://www.supremecourt.gov/about/biographyGinsburg.aspx (last visited Jan. 17, 2021).

137 See Petition for Writ of Certiorari at 9, Hidalgo v. Arizona, 138 S. Ct. 1054 (2017) (No. 17251).

138 Lowenfield v. Phelps, 484 U.S. 231, 244 (1988); Brown v. Sanders, 546 U.S. 212, 229 (2006).

139 Hidalgo v. Arizona, 138 S. Ct. 1054, 1056 (2018).
} 
places the narrowing requirement on the prosecutor, when precedent mandates that the burden fall on the legislature. ${ }^{140}$ Arizona's narrowing solution functions in the selection phase while Supreme Court precedent mandates that the narrowing occur during the eligibility phase. Second, this solution fails to look at the aggregate impact of a large number of aggravating factors in a death penalty statute.

The Arizona Supreme Court also pointed to mandatory appellate review as a safeguard against unconstitutionally low narrowing. ${ }^{141}$ The argument is that if a punishment for a particular case is much more severe than punishments in other similar cases, the Arizona Supreme Court will recognize the anomaly and remand the case for resentencing. Again, the argument fails for two reasons. First, like Arizona's previous argument, this solution places the burden on the State Supreme Court to control the narrowing function while precedent defers to the legislature for that role. Narrowing must occur during eligibility, while Arizona's second solution occurs during selection. ${ }^{142}$ Second, Arizona gave their opinion under the assumption that the statistics presented by Hidalgo were true. ${ }^{143}$ With ninetyeight percent of cases statutorily warranting the death penalty, the proportionality review becomes ineffective. It is highly unlikely that the State Supreme Court will come across the rare case where death as punishment was disproportionately severe compared to other cases when ninety-eight percent of first-degree murder cases permit death as a suitable punishment.

The Arizona Supreme Court's final proffered remedy for inadequate narrowing, an individualized sentencing determination, ${ }^{144}$ falls prey to the same fault as the earlier solutions. Individualized sentencing determinations take place during the selection phase, while Hidalgo's issue concerns only the eligibility phase. ${ }^{145}$

Although all of the safeguards against insufficient narrowing suggested by the Arizona Supreme Court do likely limit the number of individuals actually receiving death sentences in Arizona, they ignore the guiding principle that genuine narrowing must occur at the legislative stage, in the death statute itself. ${ }^{146}$

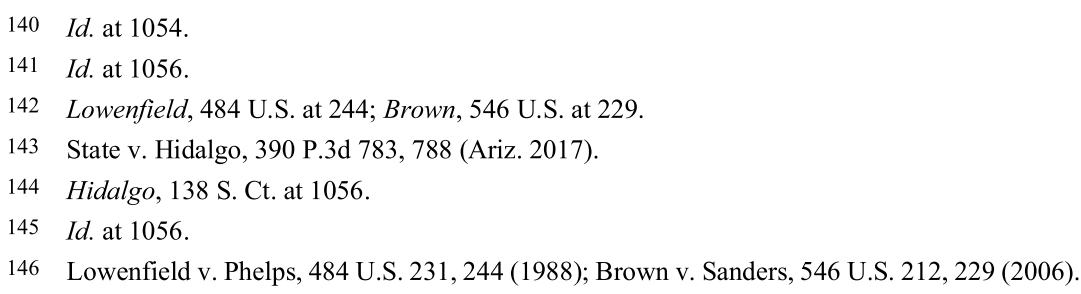




\section{B. Possible Adequate Solutions}

Although there is no simple solution, below are several suggestions to increase narrowing at the legislative level.

1. The U.S. Supreme Court Should Revisit the Issue of Adequate Narrowing.

According to the "Rule of Four," the Supreme Court may grant certiorari when four of the nine justices approve. ${ }^{147}$ Yet, the nation's highest court has never addressed the issue of what constitutes genuine narrowing. Without guidance or a standard from the Court, legislatures do not know when they have crossed the constitutional threshold. The narrowing language used by the U.S. Supreme Court in the late 1970s is meaningless today when states are free to draft statutes making ninety-eight percent of first-degree murders death eligible. The Courts should revisit the question, give effect to the nowineffective narrowing language, provide a definition of sufficient narrowing, and distinguish between sufficient and insufficient narrowing. The Court's narrowing language has never been overruled or outdated, only ignored. Justice Breyer's concurrence suggested that were a similar case accompanied by a thorough evidentiary record indicating similar statistics, the Court may grant certiorari. Justice Breyer was joined by three other justices, satisfying the Court's "Rule of Four." 148 With this in mind, defense attorneys should continue to challenge the constitutionality of the aggravating factors and the number of aggravating factors in their states. Only by making these arguments will they ever come before a court.

2. A Separate Analysis for States with Narrowing Provisions, Procedures, or Practices in the Eligibility and Selection Phases.

The intuition of the Arizona Supreme Court Justices, although mistaken, was sympathetic. The Court was likely correct in State v. Hidalgo that the

147 Supreme Court Procedures, U.S. CTS., https://www.uscourts.gov/about-federalcourts/educational-resources/about-educational-outreach/activity-resources/supreme-1 (last visited Mar. 12, 2021).

148 Id. However, after Justice Ginsburg's seat on the Court was filled by Justice Amy Coney Barrett, it is less likely that four justices would approve granting certiorari to a similar case, even with a thorough evidentiary record. Annika Russell, Supreme Court Nominee Judge Amy Coney Barrett and the Death Penalty, A.B.A. (Oct. 12, 2020), https://www.americanbar.org/groups/committees/death_penalty_representation/publications/project_blo g/amy-coney-barrett-and-the-death-penalty/. 
safeguards referenced by the court did limit the number of defendants actually selected for the death penalty. Courts cannot resolve Hidalgo's question presented about eligibility with a solution during selection. However, narrowing safeguards during selection can impact the court's analysis when reviewing eligibility. Courts should review the eligibility narrowing requirement with less scrutiny when presented with other evidence that the statute further narrows during the selection phase. After all, the U.S. Supreme Court has never prescribed a particular manner in which a state's death penalty statute must narrow—only that narrowing must occur. ${ }^{149}$

\section{Following Oregon's Example}

Twenty-nine states retain the death penalty. ${ }^{150}$ Eleven of those states have not executed any inmates in more than a decade, including Oregon, which hasn't executed any prisoners since $1997 .{ }^{151}$ In states like Oregon, which still retain death statutes but execute inmates with great infrequency, the reason may be successful narrowing.

Oregon has moved in the opposite direction as Florida and has eliminated nearly three-quarters of the aggravating factors that make a defendant eligible for the death penalty. ${ }^{152}$ In August 2019, Oregon Governor Kate Brown signed a new bill into law that eliminated fifteen of the Oregon death statute's nineteen aggravating factors. ${ }^{153}$ The governor noted that the state's criminal justice system continued to impose death sentences and send people to death row, although no one had been executed since 1997 and only two prisoners have been executed in the last fifty years. ${ }^{154}$ The new law restricts the death penalty to only those cases involving acts of terrorism in which two or more people are killed, premeditated murders of children aged

149 CARTER, ET AL., supra note 24, at 152.

150 States and Capital Punishment, NAT'L CONF. ST. Legislatures (Mar. 24, 2020), https://www.ncsl.org/research/civil-and-criminal-justice/death-penalty.aspx.

151 John Gramlich, California Is One of 11 States that Have the Death Penalty but Haven 't Used It in More than a Decade, PEW RSCH. CTR. (Mar. 14, 2019), https://www.pewresearch.org/facttank/2019/03/14/11-states-that-have-the-death-penalty-havent-used-it-in-more-than-a-decade/; Blair Stenvick, Oregon's Death Penalty Is Almost Nonexistent-So Why Can't We Get Rid of It?, PORTLAND MERCURY (Sep. 26, 2019), https:/www.portlandmercury.com/news/2019/09/26/27204581/oregonsdeath-penalty-is-almost-nonexistent-so-why-cant-we-get-rid-of-it.

152 Oregon Governor Signs Bill Narrowing Use of the Death Penalty, DEATH PENALTY INFO. CTR. (Aug. 2, 2019), https://deathpenaltyinfo.org/news/oregon-governor-signs-bill-narrowing-use-of-thedeath-penalty.

153 Id

154 Noelle Crombie, Calling Oregon Death Penalty 'Costly and Immoral,' Governor Signs Bill Limiting Its Use, OREGONIAN/OR. LIVE (Aug. 1, 2019), https://www.oregonlive.com/crime/2019/08/calling-death-penalty-costly-and-immoral-governor-signsbill-limiting-its-use.html. 
thirteen or younger, prison murders committed by those already incarcerated for aggravated murder, and premeditated murders of police or correctional officers. ${ }^{155}$

Supporters of Oregon's revised statute will limit the use of a "policy that is a fiscal, logistical, and emotional strain on Oregon's criminal justice system." 156 Before the implementation of the new law, "defense attorneys, judges, prosecutors, corrections officers, victims' family members [were] all going through this charade of the death penalty when everybody [knew it would not] be implemented." 157 The new law removes this strain on the state, and leaves "only a handful" of death-eligible crimes. ${ }^{158}$ Oregon's new law continues the trend of states moving away from the death penalty. ${ }^{159}$

The Florida state legislature should follow Oregon's lead and severely reduce the number of aggravating circumstances enumerated in the death penalty statute. It cannot be denied that Florida and Oregon have nearly opposite relationships with capital punishment. Unlike Oregon, which hasn't executed anyone in more than twenty years, Florida's most recent execution took place several months ago, three weeks after Oregon's new bill was signed into law. ${ }^{160}$ Where Oregon only has 31 inmates on death row, Florida has 336-more than ten times Oregon. ${ }^{161}$ Therefore, it seems unlikely that Florida would adopt such drastic measures as Oregon. However, Florida can and should take steps in the same direction.

Following Oregon's lead, Florida should legislatively remove some of the sixteen aggravating factors listed in the death penalty statute. Oregon eliminated nearly 75 percent of its enumerated factors; ${ }^{162}$ Florida would have to eliminate eleven or twelve of the listed factors to reach a similar proportion. Although unlikely, Florida should remove at least several, beginning with any factors duplicative of those listed in Florida's first-degree murder statute. The fourth enumerated factor states:

The capital felony was committed while the defendant was engaged, or was an accomplice, in the commission of, or an attempt to commit, or flight after committing or attempting to

\footnotetext{
155 Oregon Governor Signs Bill Narrowing Use of the Death Penalty, supra note 152.

156 Blair Stenvick, supra note 151.

157 Id.

158 Id.

159 Oregon Governor Signs Bill Narrowing Use of the Death Penalty, supra note 152.

160 Noelle Crombie, supra note 154; These Are the 99 People Executed by the State of Florida Since 1979, FLA. TIMES UNION (Aug. 21, 2019), https://www.jacksonville.com/photogallery/LK/20190821/NEWS/821009982/PH/1.

161 Noelle Crombie, supra note 154; Death Row Roster, FLA. DEP'T OF CORR.'S, http://www.dc.state.fl.us/OffenderSearch/deathrowroster.aspx (last visited Mar. 12, 2021).

162 Oregon Governor Signs Bill Narrowing Use of the Death Penalty, supra note 152.
} 
commit, any: robbery; sexual battery; aggravated child abuse; abuse of an elderly person or disabled adult resulting in great bodily harm, permanent disability, or permanent disfigurement; arson; burglary; kidnapping; aircraft piracy; or unlawful throwing, placing, or discharging of a destructive device or bomb. ${ }^{163}$

Yet, Florida's murder statute, in part, defines first-degree murder as:

[t]he unlawful killing of a human being [w] hen committed by a person engaged in the perpetration of, or in the attempt to perpetrate, any: arson, sexual battery, robbery, burglary, kidnapping, escape, aggravated child abuse, aggravated abuse of an elderly person or disabled adult, aircraft piracy, unlawful throwing, placing, or discharging or a destructive device or bomb." 164

This individual aggravating factor is duplicative of the threshold for firstdegree murder. Therefore, it achieves no narrowing and should be the first to be eliminated.

Continuing, Florida should retain only those aggravating factors that foreclose the possibility of redemption by the defendant. For example, one of the aggravating factors retained by the Oregon death penalty statute is "prison murders committed by those already incarcerated for aggravated murder." 165 This factor shows an element of near necessity or last resort. A defendant who has committed a murder within this factor was already given the opportunity for life imprisonment. Only after committing another murder, evidencing an inability to be redeemed can this defendant be sentenced to death. Florida should follow Oregon's lead.

Finally, a study similar to the one conducted in Maricopa County, Arizona, should be conducted in Florida on a state-wide scale to determine which aggravators are the most and least relied upon in Florida. A study of this type will indicate whether there are some aggravators that should be eliminated because they are not used and those that should be eliminated or modified because they are relied on often, indicating over-inclusiveness.

\section{CONCLUSION}

Florida, like many states still retaining the death penalty, has greatly departed from the genuine narrowing language the U.S. Supreme Court

\footnotetext{
163 FLA. STAT. § 921.141(6)(d) (2019).

164 FLA. STAT. $\$ 782.04(1)$ (a) (2019).

165 Oregon Governor Signs Bill Narrowing Use of the Death Penalty, supra note 152.
} 
required of all state death penalty statutes. This departure from the Court's standard violates the cruel and unusual punishments clause of the Eighth Amendment because more first-degree murders are eligible for death than ineligible. The Court should grant certiorari on this issue, precisely define for state courts what satisfies genuine narrowing, and finally require states like Florida to comply. 